\title{
Nurturing Religious and Humanistic Values to Young Generations in Gulen and Jesuit Schools in Indonesia
}

\author{
Heri Setyawan \\ Univesitas Gadjah Mada (UGM), Yogyakarta \\ hherisetya@gmail.com
}

\begin{abstract}
Abstrak
Komunitas agama memainkan peranan penting dalam mendukung pendidikan di dalam masyarakat. Sejarah mencatat, organisasi keagamaan mempunyai peran penting dalam membina dan membentuk generasi muda agar menjadi pribadi yang kuat. Fondasi keagamaan dalam sebuah lembaga pendidikan dapat menjadi sumber untuk mendidik murid dalam hal pembelajaran nilai-nilai moral. Artikel ini mencoba memahami dua komunitas agama dalam memberikan pelayanan di bidang pendidikan di Indonesia. Dua kelompok itu adalah Hizmet Movement yang terinspirasi dari tokoh Fethullah Gulen di Turki dan Serikat Jesus (SJ), kelompok imam/biarawan Katolik. Hizmet Movement di Indonesia bekerja sama dengan institusi di Indonesia mendirikan sekolahsekolah. Serikat Jesus atau Jesuit telah lama mendirikan sekolah-sekolah di Indonesia dan menjadi pionir dalam layanan pendidikan dalam sejarah Indonesia. Artikel ini akan menganalisis visi antropologi pendidikan Gulen-Inspired Schools dan sekolah Jesuit di Indonesia dalam mendidik orang-orang muda dengan pendidikan nilai. Artikel ini juga melihat program pendidikan sebagai cara untuk mengembangkan nilai-nilai pada para peserta didik.
\end{abstract}

Kata Kunci: Gerakan Hizmet, Jesuit, Pendidikan, Nilai, Spiritualitas. 


\section{Introduction}

The role of religion to support and contribute for the common good in society is manifested throughout history. One of them is through educational institutions offered by religious community to educate young generations. In the history of Indonesia itself, religious community also took its important role in educating young generation, such as through the pesantren (Islamic boarding schools) and modern schools in Islam and modern schools in Christianity. ${ }^{1}$

This writing attempts to compare two educational services offered by two religious affiliations and groups. Those are GulenInspired schools and Jesuits schools in Indonesia. It sees the anthropological foundational of their educational system and their endeavor to educate young generations with values. Comparing those schools, I assume that Jesuit and Gulen-Inspired schools have their similarities which could be a rich basis for giving services to common good in the context of Indonesia. ${ }^{2}$

Many writings about Jesuits schools itself and Gulen-Inspired schools have been published. Comparing Jesuit and Gulen-Inspired school also have been done by several academicians, such as Patrick J. Howell $^{3}$ who sees the foundational spirit of their movement and Michael David Graskemper ${ }^{4}$ who sees that both educational systems try to

\footnotetext{
1 About Pesantren, for example see Karel A. Steenbrink, Pesantren, Madrasah, Sekolab: Pendidikan Islam dalam Kurun Moderen (Jakarta: Lembaga Penelitian, Pendidikan dan Penerangan Ekonomi dan Sosial, 1986). About Catholic school in Indonesia see Floribertus Hasto Rosariyanto, Van Lith, Pembuka Pendidikan Guru di Jawa: Sejarab 150 th Serikat Jesus di Indonesia (Yogyakarta: Penerbit Universitas Sanata Dharma, 2009).

${ }^{2}$ In the academics understanding schools organized by the Hizmet Movement are called the Gulen-Inspired Schools. In Indonesia it is called Bilingual Boarding School (BBS).

3 Patrick J. Howell, "Dialogue between Jesuit and Gulen Educational and Spiritual Foundations" East and West Encounters: The Gulen Movement, http://gyv.org.tr/content/userfiles/pdf/makale-los-PATRIK J HOWELL.pdf/ accessed 23 March 2015

${ }^{4}$ Michael David Graskemper, "A Bridge to Inter-Religious Cooperation: The GulenJesuit Educational Nexus", a paper presented in the conference entitled "Muslim World
} 
educate young generation holistically which covers highly standard in science and values. This writing focuses on their way to educate young students in highly standard values in the context of Indonesia. In doing this project I did a literature review and coming to Jesuit and Gulen schools. I came to SMA Pribadi Bilingual Boarding School in Depok, West Java and Fethullah Gulen Chair in UIN Syarif Hidayatullah, Tangerang and taking information from PASIAD (Pasifik Ulkeleri Sosyal ve Itisadi Dayanisma Dernegi or Pacific Countries Social and Economic Solidarity Association) as an organization from the Gulen Movement based in Jakarta. I also came to SMP and SMA Canisius College in Jakarta to get information about Jesuit school and taking my personal experience 2 years teaching in SMA Le Cocq d'Armandville College in Nabire, Papua as a source full data.

The writing runs as follows. First, it engages with their views on education related to their spiritual foundation as a religious community. This part is important to understand to what extent their effort in educating young generation will flow. Second, it will explain their works in Indonesia particularly with its educational services in Junior and Senior High School (primary and secondary school). Third, it will focus to see their endeavors and goals in educating young generations. It will see specifically to what extent they try to educate young generation in the context of Indonesia.

\section{Foundational Spirits of Jesuit and Hizmet Movement}

Both Jesuit school and Gulen-Inspired School take their inspiration from their own leader. They also belong to a group which working in the spirit of their leader. The differences are Jesuit belong to religious orders which has a strict rule in organized institution and Hizmet movement belong to a community which their membership do not have a structural level. This part will explore 1) introduction to their community 2) their foundational inspirations taken from their leader and 2) their basic understanding on education.

in Transition: Contributions of the Gulen Movement", held at SOAS University of London, House of Lords and London School of Economics on 25-27 October 2007. 


\section{The Hizmet Movement and Its Inspirations}

Nowadays, the Gulen Movement or called the Hizmet ${ }^{5}$ Movement from Turkey spread out to several countries. The Hizmet Movement in last two decades is widely known as a movement based on the Islamic thought of Muhammad Fethullah Gulen from Turkey. The movement has been spreading to almost all over the world taking many different activities such as supporting interfaith and intercultural dialogue, supporting educational services in many forms such as thourgh founding schools, supporting scholarships and academia through publications and seminars. ${ }^{6}$ Education in many forms becomes their main concern. In Turkey itself, the Hizmet Movement also takes a complex of business network, running several media, and founding educational institutions. ${ }^{7}$ The Hizmet Movement does not only work intern in their institution but also building networking with many other institutions including state, public and private educational institution, and other religious institutions. ${ }^{8}$

The inspiration of this movement is Fethullah Gulen (b. 1941) who is well-known for his interfaith and intercultural dialogue and his thought on Islamic theology. His thought based on Islamic tradition particularly Sufism which is more open to modernity and contemporary issue. Born in the village of Korucuk, near Erzurum the influenced of

\footnotetext{
${ }^{5}$ Hizmet literary means service. See Mucahit Bilici, "Fethullah Gulen Movement and Its Politics of Representation in Turkey", in The Muslim World 96, (Januari 2006): 4. Sometimes the Hizmet Movement also referred to as Fethullahcilar and Nurcular. ${ }^{6}$ Helen Rose Ebaugh, The Gulen Movement: A Sociological Analysis of a Civic Movement Rooted in Moderate Islam (London: Springer Press, 2010), 25-41.

7 Yavuz in 1999 noted in Turkey the Hizmet Movement owns a scientific monthly (Sizinti), an environment-related magazine (Ekoloji), a theological journal (Yeni Omit), a weekly magazine (Aksiyon), a daily newspaper (Zaman), English Language religious publication (The Fountain), Samanyolu TV, and Burch FM radio. The Hizmet Movement also founds an association of businessmen and many schools. See Hakan Yavuz, "Towards an Islamic Liberalism? The Nurcu Movement and Fethullah Gulen", in Middle East Journal 53:4, (Autumn 1999): 584-605.

${ }^{8}$ For examples, the Gulen Chair as an organization which is inspired by Fethullah Gulen supports humanity activities such as promoting conflict resolution, works for freedom, justice, and democracy, interreligious dialogue.
} 
medieval Sufi such as al-Rumi, Ibn al-Arabi and al-Ghazali are embodied in his life. As a preacher in Edirne in Turkish Thrace and in Izmir, Gulen experiences a modern community compare to his hometown. As a preacher he began to organize summer camps for the youth and educates them in both secular and religious education. He promoted education for the youth. He mentions, "The most important responsibility and purpose in human life is to seek and understand the importance of education." Because of his activities and political reason he was arrested in 1971.

Gulen is influenced by Said Nursi, but in many ways he comes beyond Nursi. In his book State of Our Souls Gulen writes, Nursi "led his life in the shade of the Book and the Prophet's tradition, and under the wings of experience and logic." Gulen strongly urges his followers to educate the youth in science and social sciences as modernity flows. However, he also strongly emphasizes action in education. Service (bizmet) becomes an important part of a faith. In this line, for Gulen education does not only work for the sake of the student but also for all.

Gulen now live in the U.S. and the Hizmet Movement works in many fields in many places. As religious leader and academician Gulen conducts several meeting with other religious leaders such as Pope John Paul II in 1998, and with Jewish leader in Anti-Defamation League 1997. ${ }^{10}$ Thomas Michel mentions Fethullah Gulen and John Paul II as two frontrunners for peace. ${ }^{11}$ The role of Mr. Gulen as a preacher, writer, poet, and Islamic scholar positions him in 2008 as one of the world's top public intellectual from Foreign Public Policy magazine. The International Herald Tribune and other magazines such as The Economist also

\footnotetext{
${ }^{9}$ Hasan Aydin, "The Educational Effectiveness of Gulen-Inspired School: The Case of Nigeria" (Dissertation-University of Nevada, 2011). See also Hasan Aydin, "Educational Reform in Nigeria: The Case of Multicultural Education for Peace, Love, and Tolerance", in South African Journal of Education 33:1 (2013): 1-19.

10 See Efrat E. Aviv, "Fethullah Gülen's 'Jewish Dialogue", in Turkish Policy Quarterly 9:3, (Fall 2010): 101-115.

11 Thomas Michel, "Two Frontrunners for Peace: John Paul II and Fethullah Gülen”, paper presented at the "Frontrunners of Peace" symposia organized by the Cosmicus Foundation, Holland, at Universities in Tilburg, Erasmus, and Amsterdam, 2005.
} 
wrote about him as an inspiration for Muslims. TIME magazine in 2013 named him as World's most influential people. He was also included in 500 most influential Muslims according to Royal Islamic Strategic Studies Centre in Jordan.

2. The Jesuits and Its Inspirations

Jesuit is one of Catholic religious orders which founded in the 16th century. A Spaniard, Ignatius of Loyola (1491-1556) is its founder together with his friends who mostly at that time studied together in Paris. Jesuit as a member of Society of Jesus (SJ) began founding their first classical college in 1548 and by the end of the 16th century had established 245 colleges. ${ }^{12}$ They did those services in order to "help souls" and put it as their priority in their ministry as a Catholic orders. ${ }^{13}$ Now they are working in many activities such as giving religious services for Catholics in the Catholic Church, working in social activities such as working for ecological concerns, migrants, refuges, and human rights. In education they work in primary school up to higher levels. They also run many schools and universities.

As religious orders Jesuit lives in spirituality drown from the spirit given by Ignatius of Loyola. Unlike Gulen, Ignatius did not write his teaching, but he wrote a guidance of spiritual exercises to grow in the spirit of Christianity. It based on his mystical experience while he was in a pilgrimage to search the will of God in the river of Monserat, Spain. He wrote in his Spiritual Exercises a "first principle and foundation" which become a fundamental spirit of Jesuit and also to be shared to their followers. He begins his principle and foundation with this sentence, "Man is created to praise, reverence, and serve God our Lord and by this means to save his soul...."14 Jesuits believe that their life and all human life are primarily to serve God. In this sense, Jesuits do services to praise and serve God and by doing this it means their life are

\footnotetext{
12 Douglas Letson, Michael Higgins, The Jesuit Mystique (Chicago: Loyola Press), 135136.

${ }^{13}$ John O’Malley, The First Jesuits (Harvard: Harvard University Press, 1993), 200-202.

${ }^{14}$ Ignatius Loyola, "Spiritual Exercises", in George E. Ganss (ed.), Spiritual Exercises of Saint Ignatius: A Translation and Commentary (Chicago: Loyola Press, 1992), 232.
} 
saved. "Helping soul" is not only implemented for himself, but also for other. Jesuit services try to help other to be saved and urge other to help others.

Ignatius and his companions studied in French when the Renaissance was going to flow. A new humanism was spread out throughout the world including the church. Their goals of education are more or less in the same way with the humanists. Pedro Ribadeneira (1527-1611), a companion of Ignatius of Loyola writes a letter to King Philip II of Spain mentions as quoted above, "instituio puerorum, reformatio mundi". Jesuit's view about the world is affirmative in the sense that the world could be a good place to live and grow. In doing so, education tries to prepare the youth to achieve their highest extent and to better the world. ${ }^{15}$ Moreover, education from the very beginning is not only for the sake of the students, but for the world. Education, therefore, could give contribution to the society at large.

Jesuit school from the very beginning does not put humanistic education and science in opposition as usually occurred in that period. ${ }^{16}$ By the end of 16 centuries, Jesuit formed a Ratio Studiorum, a "program of studies" which was implemented throughout all Jesuit school. It covered educational program and way of proceeding for teachers, students, and all school administrators. Jesuit school educated students in sciences, law, medicine, and theology. Humanistic education such as through education in drama, poetry, oratory, etc. was very strong in Jesuit education. Along with it, many scientists are from Jesuit school or a Jesuit itself, such as Christopher Clavius (1538-1612) a mathematician and astronomer, Roger Boscovich (1711-1787) who is famous with his atomic theory, Pierre Teilhard de Chardin(1881-1955) a French Paleontologist. Jesuit education tries to educate young generation familiar with modernity, respect to culture, science, and values.

15 John W. O’Malley, "How the First Jesuits Became Involved in Education” in George W. Traub, A Jesuit Educational Reader (Chicago: Loyola Press), 52-53.

${ }^{16}$ John W. O’Malley, "How the First Jesuits Became Involved in Education”, 57. 


\section{Jesuit and Gulen-Inspired Schools in Indonesia}

1. The Gulen-Inspired Schools in Indonesia

The Hizmet Movement with their schools called the GulenInspired schools (elementary, junior, and high school) known in combining a highly standard of education in modern science with ethics and spirituality. ${ }^{17}$ As a result of their highly standard in science students of their schools regularly achieve national and international scientific competitions. Although the movement is rooted in a specific religion, the Gulen-Inspired schools are also accepted and success in many different places with its different cultural background. Now there are more than 1000 schools in more than 140 countries in Europe, Asia, Africa, Australia, and the United States.

In Indonesia the Gulen-Inspired schools are also rapidly growing. Starting in 1995 now there are 10 Gulen-Inspired schools which take the name Bilingual Boarding Schools spread out in many provinces and islands. In Java they are in Depok, Banten, Bandung, Tangerang, Yogyakarta, Sragen, and Semarang. They are also in Aceh, West Sumatra, and South Kalimantan. PASIAD as an organization from the Hizmet Movement are working with local institutions including nongovernment and government. They organize the Gulen-Inspired schools, build network and make collaboration with many institutions (see the table 1.). ${ }^{18}$

Their schools have been appreciated by many prominent public figures in Indonesia such as Abdurrahman Wahid (Gus Dur) a former president of Indonesia, Hidayat Nur Wahid a former leader of The People's Consultative Assembly of the Republic of Indonesia. ${ }^{19}$ They see the Gulen-Inspired Schools success to combine moral values and highly standard of science in which many schools in Indonesia takes it as a problem.

\footnotetext{
${ }^{17}$ Ihsan Yilmaz, "State, Law, Civil Society and Islam in Contemporary Turkey", in The Muslim World 95:3 (July 2005): 394.

18 The data from PASIAD, Profil Pendidikan (Jakarta: PASIAD).

${ }^{19}$ See the official website of PASIAD at http://www.pasiadindonesia.org/id/ accessed November 1, 2014.
} 
Table 1.

Gulen-Inspired Schools in Indonesia (school year 2014)

\begin{tabular}{|c|c|c|c|}
\hline Bilingual Boarding School & Collaboration & Students & Dormitory \\
\hline $\begin{array}{l}\text { SD-SMP-SMA Pribadi } \\
\text { Bilingual Boarding School } \\
\text { Depok (1995) }\end{array}$ & $\begin{array}{l}\text { Yenbu Indonesia } \\
\text { Foundation }\end{array}$ & $\begin{array}{l}\text { SD:139, } \\
\text { SMP:107, } \\
\text { SMA:124 }\end{array}$ & 79 \\
\hline $\begin{array}{l}\text { SD-SMP-SMA Semesta } \\
\text { Bilingual Boarding School } \\
\text { Semarang (1999) }\end{array}$ & $\begin{array}{l}\text { Al Firdaus Semarang } \\
\text { Foundation }\end{array}$ & $\begin{array}{l}\text { SD:160, } \\
\text { SMP:133, } \\
\text { SMA:355 }\end{array}$ & 489 \\
\hline $\begin{array}{l}\text { SD-SMP-SMA Pribadi } \\
\text { Bilingual Boarding School } \\
\text { Bandung (2002) }\end{array}$ & $\begin{array}{l}\text { Pribadi Indonesia } \\
\text { Foundation }\end{array}$ & $\begin{array}{l}\text { SD:116, } \\
\text { SMP:113, } \\
\text { SMA:251 }\end{array}$ & 133 \\
\hline $\begin{array}{l}\text { SD-SMP-SMA Fatih Bilingual } \\
\text { Boarding School Banda Aceh } \\
\text { (2005) }\end{array}$ & $\begin{array}{l}\text { Fatih Indonesia } \\
\text { Foundation }\end{array}$ & $\begin{array}{l}\text { SD:19, } \\
\text { SMP:75, } \\
\text { SMA:113 }\end{array}$ & 102 \\
\hline $\begin{array}{l}\text { SD-SMP-SMA Kharisma } \\
\text { Bangsa Bilingual Boarding } \\
\text { School Tangerang Selatan } \\
\text { (2006) }\end{array}$ & $\begin{array}{l}\text { Kharisma Bangsa } \\
\text { Foundation }\end{array}$ & $\begin{array}{l}\text { SD:163, } \\
\text { SMP:164, } \\
\text { SMA:317 }\end{array}$ & 250 \\
\hline $\begin{array}{l}\text { SMP-SMA Sragen Bilingual } \\
\text { Boarding School Sragen (2008) }\end{array}$ & $\begin{array}{l}\text { Local Government of } \\
\text { Sragen }\end{array}$ & $\begin{array}{l}\text { SMP:70, } \\
\text { SMA:165 }\end{array}$ & 235 \\
\hline $\begin{array}{l}\text { SD-SMP-SMA Teuku Nyak } \\
\text { Arif-Fatih Banda Aceh (2009) }\end{array}$ & $\begin{array}{l}\text { Fatih Banda Aceh } \\
\text { Foundation }\end{array}$ & $\begin{array}{l}\text { SD:190, } \\
\text { SMP:64, } \\
\text { SMA:106 }\end{array}$ & 103 \\
\hline $\begin{array}{l}\text { SMP-SMA Kesatuan Bangsa } \\
\text { Bilingual Boarding School } \\
\text { Yogyakarta (2011) }\end{array}$ & $\begin{array}{l}\text { Kesatuan Bangsa } \\
\text { Mandiri Yogyakarta } \\
\text { Foundation } \\
\end{array}$ & $\begin{array}{l}\text { SMP:73, } \\
\text { SMA:204 }\end{array}$ & 264 \\
\hline $\begin{array}{l}\text { SMAN Banua Bilingual } \\
\text { Boarding School Banjarmasin, } \\
\text { South Kalimantan (2012) }\end{array}$ & $\begin{array}{l}\text { Local Government of } \\
\text { South Kalimantan } \\
\text { Province }\end{array}$ & SMA:124 & 124 \\
\hline SMAN 1 Sumatera Barat (2014) & $\begin{array}{l}\text { Local Government of } \\
\text { West Sumatra } \\
\text { Province }\end{array}$ & SMA:260 & 260 \\
\hline
\end{tabular}

Although the Gulen-Inspired schools in Indonesia are newcomers, their quality has been respected by Indonesian academia. Their students regularly achieve medals on several international and national competitions. In July 2014, six students from several GulenInspired schools in Indonesia got medals prizes from international Olympiad. They got a silver medal in International Biology Olympiad (IBO) in Bali, Indonesia, a silver medal in International Chemistry Olympiad (IchO) in Hanoi, Vietnam, a bronze medal in International 
Olympiad in Informatics (IOI) in Taipei, Taiwan, a bronze medal in International Physics Olympiad (IphO) in Astana, Kazakhstan, silver and bronze medal in International Mathematic Olympiad (IMO) in Cape Town, South Africa. In national level the Gulen-Inspired Schools in Indonesia also got 43 medal from National Science Olympiad (OSN) held in Mataram, Nusa Tengara Barat, September 2014..$^{20}$ In 2013 they got 45 medals. Those positions have put the Gulen-Inspired school along with other famous high schools in Indonesia, such as SMAK BPK Penabur Jakarta, SMA Canisius College Jakarta, SMAK Petra 2 Surabaya, and other public schools.

As institution under the PASIAD, the Gulen-Inspired Schools are also doing collaboration especially for the student. They have Kompetisi Matematika PASIAD (KMP, Mathematic Competition) and other competition such as debating in foreign language and cultural event. PASIAD is very active in promoting educational scholarship in the national and international contexts. For examples, PASIAD held Indonesian Science Project Olympiad, International Science Project Olympiad, Olimpiade Seni dan Babasa Indonesia (Art and Bahasa Indonesia Olympiad), and PASIAD Education Awards.

The Gulen-Inspired School has a dormitory for the students. The students have a tight schedule such as to do prayers, sport, recreation, and study. Several administrators would accompany them in their daily study. The PASIAD sent several teachers to the GulenInspired School, teaching in the school and became an administrator of the school. Mostly teacher from Turkey teach science such as chemistry, mathematics, physics, and others. The administrators of the dormitory are from Turkey. In school and dormitory they work with Indonesians.

2. Jesuit Schools in Indonesia

Working in Indonesia, from the very beginning Jesuit gave services in education. Van Lith who came to Java in the end of 19 century founded a primary school (1900) and school teacher (1906) in Muntilan, Central Java. Those schools graduated several public figures in Indonesia who played important role in the independence of Indonesia.

${ }^{20}$ Ibid. 
Those schools transformed in many forms which now become SMPSMA Van Lith run by FIC, a worldwide religious community within the Catholic church.

Now, Jesuit in Indonesia runs eight secondary schools or senior high schools spread out in many places in Indonesia. Running those colleges Jesuit also works as administrator and teacher. They also become administrator of two large educational foundations in Central Java (Kanisius Foundation) and in Jakarta (Strada Foundation) which belong to local church. Those foundations have many primary and secondary schools in Central Java and Jakarta.

Table 2.

Jesuit Schools in Indonesia (school year 2015)

\begin{tabular}{|l|l|}
\hline Schools & Students \\
\hline SMP-SMA Canisius College, Jakarta (1927) & $\begin{array}{l}\text { SMP: 600 students } \\
\text { SMA: 676 students }\end{array}$ \\
\hline SMA Loyola College, Semarang (1949) & 725 students \\
\hline SMA de Britto College, Yogyakarta (1949) & 714 students \\
\hline $\begin{array}{l}\text { SMK Mikael, Surakarta (vocational school for enginering, } \\
\text { 1962) }\end{array}$ & 670 students \\
\hline SMA Gonzaga, Jakarta (1987) & 750 students \\
\hline SMA Mertoyudan Minor Seminary, Magelang (1925) & 235 students \\
\hline $\begin{array}{l}\text { SMK PIKA, Semarang (vocational school of woodworking } \\
\text { technology, 1968) }\end{array}$ & 160 students \\
\hline SMA Le Cocq d'Armandville, Papua (2000) & $\begin{array}{l}335 \text { students, } \\
\text { dormitory: } 65 \\
\text { students }\end{array}$ \\
\hline
\end{tabular}

In school Jesuits become administrator and teacher. The principle for Jesuit schools mostly is a Jesuit. Jesuit also becomes a moderator or vice principle that are responsible for educating students in characters. Jesuits also teach some classes, such as teaching religion, history, or language. De Britto College, Mertoyudan Minor Seminary and Canisius College only educate boys, while others for both boys and girls. Le Cocq d'Armandville college is special because it is in Papua and it tries to give priority for Papuans who mostly have a bad service in education. Many students come to senior high school still illiterate because of lack educational services in their village. For Papuans, Jesuit school prepares a dormitory so that they could be accompanied intensively.

32 | Heri Setyawan - Nurturing Religious and Humanistic Values to Young Generations 


\section{Special Characteristics of Gulen-Inspired Schools and Jesuit Schools}

Both, Jesuit and Gulen-Inspired schools play its role in educating young generation in science and values. Those schools represent a higher standard of science. Moreover, they also rooted in religiosity so that it could cover the character of the students. Abdurrahman Wahid (Gus Dur) said about Gulen-inspired school that, "In term of education, we can learn from the experience of Said Nursi and Fethullah Gulen from Turkey who take moral values (akblak yang mulia) into their schools." Gus Dur also continued, "Moral values are very important for Indonesia because our schools are now lack of morality." 21

Both schools give their best effort in educating young people to have a higher standard of science. They are very positive to modernity such as giving priority to learn about science, technology, and globalization. They educate their students in science, technology, following and giving response to contemporary issues both in global and local area. As Henry A. Giroux mentions, modernity has two faces. It gives benefit for society but also it challenges education because "social modernity" places progress as its center and person is evaluated through its progress. ${ }^{22}$ Social modernity reflects the progress of technology, science, and economic development. In the modern era, student is pushed to follow and master in all those things. In these contexts, Jesuit and Gulen-Inspired school urges their students to grow as modernity asks to do. Those schools try to educate their students master in science so that they could live within modernity.

The highly standard in science which becomes one of the main values of Gulen-Inspired school is in accordance with the Jesuit school's values that is competence. Jesuit school stands three core values those are competence, conscience, and compassion. Competence that is the ability to learn and expert in study becomes their principle.

21 Ibid.

${ }^{22}$ Henry A. Giroux, "Rethinking the Boundaries of Educational Discourse: Modernism, Postmodernism, and Feminism", in College Literature (1990): 6-7. 
As a social phenomenon, social modernity might not be avoided. Giroux continues that in those contexts, the place of cultural studies in the education system should be placed in its center. Cultural studies should help student to be a fully human, not as a machine or technology as the modernity usually want to. Looking at the practices of education in Gulen and Jesuit school, they take values as their core pedagogy. Values puts person as an individual in a social context.

As an individual, Jesuit school takes conscience as its values. Conscience which is required awareness and truthfulness invites students to have a pure heart and be authentic. Canisius College takes honesty as one of their first practical values so that if they do cheating during the test they will be fired without any discussion. Gulen School also practices conscience in their pedagogy. As Gulen states in Key Concepts in the Practice of Sufism, Gulen-Inspired school practices "virtuous circle" which put "inner conscience and the brightness of his inner conscience strengthen his will-power resolve, stimulating him to higher horizons". ${ }^{23}$ Gulen also writes that education leads person to have ability to make a right decision. "Right decisions depend on having a sound mind and being capable of sound thought". ${ }^{24}$ Both schools educate their students to have integrity as a person both in heart and mind.

Regarding solidarity, both schools highly promote service. Gulen-Inspired schools put service as their central values. Service is a practice of love. It is an action. Gulen shows that all teaching should come out with action and the action is service. Helping others become their main values as the Hizmet is their name. Jesuit school also put is as their central values. "Men and women for others" is their motto which from the very beginning being introduced to the students. The third values which should be learn every time for them is compassion which takes them to solidarity. In the educational process they do an immersion in the rural area or in village in Central Java or other places. They live with the farmers, helping them in the field, etc.

23 As quoted by Trudy D. Conway, Cross-cultural Dialogue on the Virtues: The Contribution of Fethullah Gülen (Cham: Springer International Publishing, 2014), 14-15.

${ }^{24}$ As quoted by Michael David Graskemper, "A Bridge to Inter-Religious Cooperation: The Gulen-Jesuit Educational Nexus”, 630. 
Modernity is a challenges for education. Moreover, Giroux also put postmodernity as a challenge for education. The rise of postmodernity which comes to the rejection of metanarratives, totality, and foundationalism could be occurred in education. However, Giroux also optimistic those other values are in the center of this phenomenon. The notion of postmodernity also urges people to accept multiculturalism. Gulen-Inspired schools which tend to be more global and international are challenged with this phenomenon. However, Gulen-Inspired schools also have their educational system to introduce student to the local culture and experience diversity. They have cultural events which both covers global and local culture. Jesuit schools are also challenged because some Jesuit schools mostly only have students from one ethnicity. Although both schools accept students from difference religious affiliations, it is only small number. They are challenged to be more opened and to experience diversity.

\section{Conclusion}

Looking at the practices of education in Gulen-Inspired schools and Jesuit schools above it is an inspiration to take education as a starting point to better the world. Education prepares young generation to have ability to adjust with science, modernity and social differences. Religious foundation of the school could be a source to educate students in social values. Education does not only concern with the need of each student, but also prepare students to work for common good in society.

Both Gulen-Inspired school and Jesuit school teach highly standard in science and value. Science and value do not in separation. Moreover, both science and value are embodied together to the students. Those schools which based on religious affiliations could be a source full place to synthesize religiosity, modernity, and social virtues to building the future civilization. 


\section{Bibliography}

Aviv, Efrat E. "Fethullah Gülen's 'Jewish Dialogue", in Turkish Policy Quarterly 9:3, (Fall 2010): 101-115.

Aydin, Hasan. The Educational Effectiveness of Gulen-Inspired School: The Case of Nigeria. Dissertation-University of Nevada, 2011.

Aydin, Hasan. "Educational Reform in Nigeria: The Case of Multicultural Education for Peace, Love, and Tolerance". In South African Journal of Education 33:1. 2013.

Bilici, Mucahit. "Fethullah Gulen Movement and Its Politics of Representation in Turkey". In The Muslim World 96, January 2006, 1-20.

Conway, Trudy D. Cross-cultural Dialogue on the Virtues: The Contribution of Fetbullah Gülen. Cham: Springer International Publishing, 2014.

Ebaugh, Helen Rose. The Gülen Movement: A Sociological Analysis of a Civic Movement Rooted in Moderate Islam. London: Springer Press, 2010.

Ganss, George E. (ed.). Spiritual Exercises of Saint Ignatius: A Translation and Commentary. Chicago: Loyola Press, 1992.

Giroux Henry A. "Rethinking the Boundaries of Educational Discourse: Modernism, Postmodernism, and Feminism". In College Literature (1990): 1-50.

Graskemper, Michael David. "A Bridge to Inter-Religious Cooperation: The Gulen-Jesuit Educational Nexus", a paper presented in the conference entitled "Muslim World in Transition: Contributions of the Gulen Movement", held at SOAS University of London, House of Lords and London School of Economics on 25-27 October 2007.

Gülen, Fethullah. Essentials of the Islamic Faith. Fairfax, VA: The Fountain. 2000.

Gülen, Fethullah. Pearls of Wisdom, New Jersey: The Light, Inc., 2005.

Howell, Patrick J. "Dialogue between Jesuit and Gulen Educational and Spiritual Foundations". East and West Encounters: The Gulen 
Movement, http://gyv.org.tr/content/-userfiles/pdf/makalelos-PATRIK_J_HOWELL.pdf

Letson, Douglas and Michael Higgins. The Jesuit Mystique. Chicago: Loyola Press, 1995.

Michel SJ, Thomas. "Two Frontrunners for Peace: John Paul II and Fethullah Gülen". Paper presented at the "Frontrunners of Peace" symposia organized by the Cosmicus Foundation, Holland, at Universities in Tilburg, Erasmus, and Amsterdam, 2005.

O'Malley, John W. The First Jesuits. Harvard: Harvard University Press, 1993.

Rosariyanto, Floribertus Hasto. Van Lith, Pembuka Pendidikan Guru di Jawa: Sejarah 150 th Serikat Jesus di Indonesia. Yogyakarta: Penerbit Universitas Sanata Dharma, 2009.

Steenbrink, Karel A. Pesantren, Madrasah, Sekolah: Pendidikan Islam dalam Kurun Modern. Jakarta: Lembaga Penelitian, Pendidikan dan Penerangan Ekonomi dan Sosial, 1986.

Traub, George W. A Jesuit Educational Reader. Chicago: Loyola Press, 2008.

Yavuz, Hakan. "Towards an Islamic Liberalism? The Nurcu Movement and Fethullah Gulen". In Middle East Journal 53:4, (Autumn 1999): 584-605.

Yilmaz, Ihsan. "State, Law, Civil Society and Islam in Contemporary Turkey". In The Muslim World 95:3 (July 2005) 